\title{
A pandemic of hindsight?
}

\author{
We must learn lessons from the handling of the flu pandemic to improve future research and public-health \\ responses to emerging diseases, but retrospective hindsight and recriminations are not the answer.
}

ate this week, the Council of Europe's parliamentary assembly, a 47-member-state body that promotes democracy and human

_rights in Strasbourg, France, is scheduled to vote on a resolution expressing alarm over the World Health Organization's (WHO's) handling of the H1N1 influenza pandemic.

The council should think twice. In conversations with more than a dozen flu researchers and public-health officials from Australia, the United States, the United Kingdom and several other countries, Nature heard many objections to the conclusions of the report on which the resolution is based. Angus Nicoll, a senior influenza expert at the European Centre for Disease Prevention and Control (ECDC) in Stockholm, says that in the ECDC's opinion: "The conclusions of the report do not fit the facts as we see them, and as are backed up by science."

Certainly, the council's inquiry into the pandemic started off by taking a strong angle, with a December 2009 parliamentary motion entitled 'Faked pandemics - a threat for health'. The motion asserted that "to promote their patented drugs and vaccines against flu, pharmaceutical companies have influenced scientists and official agencies, responsible for public health standards, to alarm governments worldwide".

Similar ideas are reiterated in the inquiry's draft final report, which was adopted on 4 June by the council's health committee, and which also contains the resolution to be voted on this week (see go.nature. com/txThYG). "Drug firms 'encouraged world health body to exaggerate swine flu threat," declared Britain's Daily Mail newspaper that day, in a typical headline.

It is this kind of response that the WHO's defenders find so potentially damaging - not least because it can only encourage the conspiracy theories that already swirl around the pandemic, and diminish public confidence in health authorities. It is indeed vital that health authorities are transparent in their dealings with industry. But the drug industry is a necessary partner in a pandemic response, as the producer of antivirals and vaccines. It would have been irresponsible to exclude top academic experts from the decision-making just because of industrial competing interests, which do not necessarily represent conflicts of interest. Critics also tend to forget that in spring 2009 the WHO and national officials were struggling with large scientific uncertainties, and the possibility that millions of people would die if the response was inadequate (a reality that the Council of Europe report does acknowledge).

Paul Flynn, a UK Labour Member of Parliament and rapporteur of the inquiry, says he could not fully address Nature's queries as to the accuracy of the science of some statements in the report, given the short deadline, but says he feels that these are minor and do not significantly alter its conclusions. "I will, of course consider your comments, but our concerns remain unchallenged," he says, adding that he would have any errors corrected in the final report. He questions the criticism of the report, saying that he believes industry lobbyists are working to undermine it.

The resolution states that the council is "alarmed" about the WHO's, the European Union's and national governments' handling of the pandemic, arguing that some decisions taken led to "distortion of priorities of public health services across Europe, waste of large sums of public money, and also unjustified scares and fears about health risks faced by the European public at large". It also affirms its concern over possible "undue influence" on decisions by the pharmaceutical industry. Some of its recommendations, such as calls for greater transparency, and creating a public fund for research and trials independent of industry, are sensible. But many researchers dispute its highly critical analysis of the pandemic response, which is expanded on in an accompanying 15-page explanatory memorandum.

That said, however, there are plenty of lessons to be learned from the WHO's response to the pandemic. Fortunately, there is at least one independent review that seems to be looking for those lessons in the right way - slowly and impartially, and without indulging in 20/20 hindsight. The 29-member panel, chaired by Harvey Fineberg, the president of the US Institute of Medicine, is due to deliver its findings at next year's World Health Assembly. Meanwhile, several national investigations are also under way - as the flu pandemic played out, it was largely national governments, at least in the rich countries, not the WHO, that led the pandemic responses. And they have plenty of their own lessons to learn.

\section{A full accounting}

\section{The BP spill should help make the case for bringing ecosystem services into the economy.}

n 14 June, BP promised to put US $\$ 20$ billion into an escrow account to pay for damage caused by the 22 April sinking of its Deepwater Horizon drilling platform off the coast of Louisiana - an event that has left a geyser of crude oil gushing into the Gulf of Mexico for two months, at a rate currently estimated as high as 60,000 barrels (9.5 million litres) a day. The beneficiaries of this fund are expected to be fishermen, hoteliers, charter-boat operators and other Gulf-coast business owners who have lost income, as well as states and other entities with clean-up costs.

Left unclear, however, is whether payment will ever be made for the loss of 'ecosystem services' that benefit everyone but are owned by no one. One such service is the carbon sequestration provided by marsh plants and ocean plankton. How will BP make good the value lost if the oil kills enough of them to hasten climate change? Another service is the buffering that coastal marshes provide to nearby communities from the Gulf's many hurricanes. 